\title{
Binding and neutralization of vascular endothelial growth factor (VEGF) and related ligands by VEGF Trap, ranibizumab and bevacizumab
}

\author{
Nicholas Papadopoulos • Joel Martin • Qin Ruan • Ashique Rafique • \\ Michael P. Rosconi • Ergang Shi • Erica A. Pyles • George D. Yancopoulos • \\ Neil Stahl $\cdot$ Stanley J. Wiegand
}

Received: 30 September 2011 / Accepted: 17 December 2011/Published online: 3 February 2012

(C) The Author(s) 2012. This article is published with open access at Springerlink.com

\begin{abstract}
Pharmacological inhibition of VEGF-A has proven to be effective in inhibiting angiogenesis and vascular leak associated with cancers and various eye diseases. However, little information is currently available on the binding kinetics and relative biological activity of various VEGF inhibitors. Therefore, we have evaluated the binding kinetics of two anti-VEGF antibodies, ranibizumab and bevacizumab, and VEGF Trap (also known as aflibercept), a novel type of soluble decoy receptor, with substantially higher affinity than conventional soluble VEGF receptors. VEGF Trap bound to all isoforms of human VEGF-A tested with subpicomolar affinity. Ranibizumab and bevacizumab also bound human VEGF-A, but with markedly lower affinity. The association rate for VEGF Trap binding to VEGF-A was orders of magnitude faster than that measured for bevacizumab and ranibizumab. Similarly, in cell-based bioassays, VEGF Trap inhibited the activation of VEGFR1 and VEGFR2, as well as VEGF-A induced calcium mobilization and migration in human endothelial cells more potently than ranibizumab or bevacizumab. Only VEGF Trap bound human PlGF and VEGF-B, and inhibited VEGFR1 activation and HUVEC migration induced by PIGF. These data differentiate VEGF Trap from ranibizumab and bevacizumab in terms of its markedly
\end{abstract}

Electronic supplementary material The online version of this article (doi:10.1007/s10456-011-9249-6) contains supplementary material, which is available to authorized users.

N. Papadopoulos · J. Martin · Q. Ruan · A. Rafique .

M. P. Rosconi - E. Shi - E. A. Pyles - G. D. Yancopoulos ·

N. Stahl · S. J. Wiegand $(\square)$

Regeneron Pharmaceuticals Inc., 777 Old Saw Mill River Road,

Tarrytown, NY 10591, USA

e-mail: stanley.wiegand@regeneron.com higher affinity for VEGF-A, as well as its ability to bind VEGF-B and PlGF.

Keywords VEGF receptor - Aflibercept - Affinity · Age-related macular degeneration · Placental growth factor

$\begin{array}{ll}\text { Abbreviations } \\ \text { AMD } & \text { Age-related macular degeneration } \\ \text { HUVEC } & \text { Human umbilical vein endothelial cells } \\ \text { VEGF } & \text { Vascular endothelial growth factor } \\ \text { VEGFR } & \text { VEGF receptor } \\ \text { PIGF } & \text { Placental growth factor }\end{array}$

\section{Introduction}

Angiogenesis is the process by which new vessels are created from pre-existing vasculature. Abnormal angiogenesis is a hallmark of diseases such as cancer [1] and the neovascular or 'wet' form of age-related macular degeneration (AMD) [2], the leading cause of blindness in the elderly population [3]. The process is characterized by an increase in the number of proliferating endothelial and stromal cells, and altered morphology of the vasculature $[4,5]$. Several proangiogenic factors are consistently upregulated during diverse forms of pathological angiogenesis, including two members of the vascular endothelial growth factor (VEGF) family, VEGF-A and placental growth factor (PlGF) [6-8]. These factors activate quiescent endothelial cells and promote cell proliferation, migration and vascular permeability [5-9]. As in cancer, VEGF-A is the major driver of pathological angiogenesis and vascular leak in wet AMD, as well as in other ocular vascular diseases, such as diabetic and ischemic 
retinopathies. Moreover, growing evidence suggests that PIGF synergizes with VEGF-A in promoting vascular pathology in these diverse conditions [10-16].

In humans and other mammals, the VEGF family of factors consists of five related glycoproteins, VEGF-A, -B, $-\mathrm{C},-\mathrm{D}$ and PIGF $[17,18]$. VEGF-A is the first, and most well studied member of the VEGF family and is currently a key target for antiangiogenic therapy [17]. Although encoded by a single gene, several distinct isoforms of VEGF-A exist as a result of alternative splicing and/or proteolytic cleavage. The various VEGF-A isoforms are all active as dimers, differing principally in their size and their ability to bind heparin or accessory, non-signaling binding proteins called neuropilins. For example, VEGF- $\mathrm{A}_{165}$ binds heparin and neuropilins with low affinity, and is the predominant isoform expressed in humans. VEGF- $\mathrm{A}_{121}$ is also expressed at high levels in many tissues and in pathological conditions, but it lacks the domains that mediate binding to heparin and neuropilins [17, 18] and is thus freely diffusible. Other isoforms such as VEGF-A ${ }_{189}$ and VEGF-A 206 bind heparin with high affinity and thus accumulate in the extracellular matrix. Isoforms of VEGF-B and PIGF, which differ in their capacity to bind heparin and/or neuropilins are also produced by alternative splicing.

VEGF family ligands bind with high affinity to and signal through three receptor tyrosine kinases, VEGFR1, VEGFR2 and VEGFR3 [8, 17-19]. VEGFR2 is expressed predominantly on vascular endothelial cells. In addition to being expressed on the vascular endothelium, VEGFR1 is also expressed by several other cell types including neutrophils, monocytes, macrophages, mural cells, and endothelial progenitor cells. Although VEGFR1 has a higher affinity for VEGF-A than does VEGFR2, in endothelial cells VEGFR1 exhibits only weak tyrosine phosphorylation when activated by VEGF-A induced dimerization. Thus, the effects of all isoforms of VEGF-A on the vascular endothelium are thought to be mediated primarily through activation of VEGFR2. PIGF and VEGF-B bind only to VEGFR1, and in further contrast to VEGF-A, neither PIGF nor VEGF-B are essential for normal vascular development or physiological angiogenesis in the adult. However, like VEGF-A, both PIGF and VEGF-B have been implicated in pathological vascular remodeling $[8,11,18]$. The remaining VEGF family members, VEGF-C and VEGF-D, bind with high affinity to VEGFR3. VEGFR3 is found primarily on lymphatic endothelial cells in the adult. Consequently, VEGF-C and VEGF-D are involved primarily in the regulation of lymphangiogenesis [19], although VEGFR3 signaling is also thought to be important for both developmental and tumor angiogenesis [20-22].

The arsenal of VEGF blockers has evolved over time, with newer generations offering potentially improved antiangiogenic activity by increasing their affinity for VEGF-
A, and/or the number of VEGF-isoforms and family members that they inhibit. Pegaptanib (Macugen ${ }^{\mathrm{TM}}$, Eyetech, Inc.) is an aptamer that selectively binds to and neutralizes VEGF- $\mathrm{A}_{165}$, but not VEGF- $\mathrm{A}_{121}$, and was the first anti-VEGF therapy approved for the treatment of wet AMD [23, 24]. Bevacizumab (Avastin ${ }^{\circledR}$, Genentech, Inc.) is a recombinant, humanized monoclonal antibody that binds all isoforms of VEGF-A, and has been approved for the treatment of metastatic colorectal cancer, non-smallcell lung cancer, and glioblastoma multiforme [1, 25]. Ranibizumab (Lucentis ${ }^{\circledR}$, Genentech, Inc.) was developed specifically for intravitreal administration to treat vascular eye diseases, notably the wet or neovascular form of AMD [26, 27]. Ranibizumab is an affinity-matured antigenbinding fragment $(\mathrm{Fab})$ derived from bevacizumab, and thus has a higher affinity for VEGF-A relative to that of the parental bevacizumab Fab molecule (Fab-12) [28]. Ranibizumab was developed as a Fab because the smaller size was thought to enhance its diffusion from the vitreous into the retina and choroid, relative to full-length antibodies [26]. Being an antibody Fab fragment, each ranibizumab molecule has one binding site for VEGF (compared to bevacizumab's two), such that two molecules of ranibizumab are bound by each VEGF dimer. In clinical trials, pegaptanib was shown to have a modest effect in slowing the rate of vision loss in patients with wet AMD, while ranibizumab has proven to be highly effective not only in reducing macular edema and preventing further vision loss, but also in producing clinically meaningful improvements in vision in significant numbers of patients $[26,29,30]$. Ranibizumab has been approved by the FDA for the treatment of wet AMD, while bevacizumab is also currently used off-label to treat AMD by intravitreal administration. While the comparative safety and efficacy of bevacizumab for the treatment of wet AMD have not yet been definitively established, several large, controlled clinical trials comparing the relative efficacy of ranibizumab and bevacizumab in the wet AMD are in progress [31, 32].

VEGF Trap (aflibercept, Regeneron Pharmaceuticals, Inc.) is a novel type of soluble decoy receptor generated with Trap technology [33], which employs the fusion of components from multiple endogenous receptors. VEGF Trap consists of an all human amino-acid sequence and comprises the second Ig domain of human VEGFR1 and the third Ig domain of human VEGFR2 expressed as an inline fusion with the constant region $(\mathrm{Fc})$ of human $\mathrm{IgG} 1$ [34]. Like bevacizumab and ranibizumab, VEGF Trap binds multiple isoforms of VEGF-A [35] but in contrast to these antibodies the VEGF Trap was designed to also bind the related VEGFR1 ligands, VEGF-B and PIGF. An intravenous formulation of VEGF Trap, generically known as aflibercept, is being developed for use in oncology 
[ZALTRAP $^{\mathrm{TM}}$ (aflibercept)]; this formulation is hyperosmotic and diluted prior to infusion. An alternate formulation of aflibercept, known as VEGF Trap-Eye [EYLEA $^{\mathrm{TM}}$ (aflibercept) Injection)], is an ultra-purified and iso-osmotic drug product that has been developed specifically for intravitreal injection for use in the treatment of various ophthalmological conditions.

Although some data on the binding affinities and in vitro activities of bevacizumab, ranibizumab and VEGF Trap have been published [28, 34, 36-40], the available data are incomplete. Moreover, comparison of the currently available data for these agents across publications is problematic as the experimental methods, cell lines, and particular conditions employed differ significantly from study to study. For example, the equilibrium dissociation constant $\left(K_{\mathrm{D}}\right)$ of the Fab fragment of bevacizumab (Fab-12) for VEGF-A has been variously reported as 1.8 and $20 \mathrm{nM}$, as determined by surface plasmon resonance (SPR) technology (Biacore) $[28,36]$, while the binding characteristics of the full bivalent bevacizumab molecule have not been reported. Thus, the goal of the present work was to assess the binding properties and in vitro activity of VEGF Trap, ranibizumab and bevacizumab under identical experimental conditions.

The results of these experiments show that VEGF Trap binds to VEGF-A with higher affinity and a faster association rate than ranibizumab or bevacizumab, and that VEGF Trap has the unique ability to additionally bind VEGF-B and PlGF. Consistent with its higher affinity for VEGF-A and faster association rate, VEGF Trap demonstrates increased potency relative to ranibizumab and bevacizumab in blocking VEGF-A induced activation of VEGFR1 and VEGFR2 in cell-based assays, and also in blocking VEGF-mediated calcium mobilization and migration in human endothelial cells. Finally, the high affinity binding of VEGF Trap to PlGF is borne out by the finding that only VEGF Trap can markedly inhibit VEGFR1 activation and endothelial cell migration induced by PlGF.

\section{Materials and methods}

\section{VEGF reagents}

Human VEGF-A 121 , human PlGF-1, human VEGF-C, human VEGF-D, murine VEGF-A $\mathrm{A}_{164}$, murine VEGF-A $\mathrm{A}_{120}$, murine PlGF-2, rat VEGF-A 164 , human VEGFR1-hFc, human VEGFR2-hFc and hVEGFR3-hFc were purchased from R\&D Systems (Minneapolis, MN). VEGF Trap, rabbit VEGF-A ${ }_{165}$, human PlGF-2, human VEGF-B (10-108) and human VEGF-A 165 were made at Regeneron Pharmaceuticals, Inc. (Tarrytown, NY). Bevacizumab and ranibizumab (Genentech, Inc., South San Francisco, CA) were purchased.
Surface plasmon resonance (SPR)

SPR experiments were performed on a Biacore 3000 instrument using a dextran-coated (CM5) chip at $25^{\circ} \mathrm{C}$. The running buffer was filtered HBS-T (10 mM Hepes, $150 \mathrm{mM} \mathrm{NaCl}, 3.4 \mathrm{mM}$ EDTA, $0.05 \%$ polysorbate $20, \mathrm{pH}$ 7.4). A capture sensor surface was prepared by covalently immobilizing recombinant Protein A (Pierce, Rockford, IL) or an anti-human Fab polyclonal antibody (human Fab capture kit, GE Healthcare, Piscataway, NJ) to the chip surface using (1-Ethyl-3-[3-dimethylaminopropyl]carbodiimide hydrochloride)/N-hydroxysuccinimide (EDC/NHS) coupling chemistry. Following surface activation, Protein A or anti-human Fab polyclonal antibody in coupling buffer ( $0.1 \mathrm{M}$ acetate buffer, $\mathrm{pH} 4.5)$ was injected over the activated chip surface until a resonance unit (RU) signal of about 2,000 RU (Protein A) or 1,000 RU (anti-human Fab polyclonal antibody) was reached. The activated coupled chip surfaces were then washed and treated with $10 \mathrm{mM}$ glycine- $\mathrm{HCl}, \mathrm{pH} 1.5$, to remove uncoupled residual proteins.

VEGF Trap, bevacizumab or ranibizumab were diluted into the running buffer and captured on the coupled Protein A (VEGF Trap and bevacizumab) or anti-human Fab polyclonal antibody (ranibizumab) chip surface. Following the capture step, a range of concentrations of test ligands (1.0-0.062 nM for VEGF-A ligands, 2.5-0.156 nM for VEGF-B ${ }_{(10-108)}$ and 5.0-0.078 nM for PlGF ligands) were individually injected over VEGF inhibitor captured surfaces. For all ligands, the association rate constant $\left(k_{\mathrm{a}}\right)$ was determined from data obtained at multiple test ligand concentrations. The dissociation rate constant $\left(k_{\mathrm{d}}\right)$, which is independent of test ligand concentration, was determined from the change in VEGF inhibitor-bound test ligand RU over time ( 10-70 min) for PlGF and VEGF-B ligands. Since the dissociation rate $\left(k_{\mathrm{d}}\right)$ of VEGF-A family ligands is too slow to allow for sufficient RU change within ligand dissociation time periods typically employed, the dissociation rates for these ligands were measured on a Biacore 2000 instrument using the "fixed $k_{\mathrm{d}}$ " procedure as described by Drake et al. [41]. This format uses a saturating concentration of ligand for binding, followed by monitoring the dissociation rate for an extended period of time ( 2-3 h). Specific Biacore kinetic sensorgrams (Online Resource 1, Figures 1-5) were obtained by a double referencing procedure as described by Myszka et al. [42]. The data were then processed using Scrubber software (version 2.0, BioLogic Software) and kinetic analyses performed using BiaEvaluation (version 4.1, Biacore). The equilibrium dissociation constant $\left(K_{\mathrm{D}}\right)$ was calculated from the ratio of the dissociation rate constant divided by the association rate constant $\left(K_{\mathrm{D}}=k_{\mathrm{d}} / k_{\mathrm{a}}\right)$. Similar studies were conducted to evaluate the binding kinetics of VEGF-A 165 
to the extracellular domains of native VEGFR1 and VEGFR2 fused to human Fc (Online Resource, Fig. 5) and several other VEGF family related ligands from multiple species (Online Resource 1, Table 1). Additional studies demonstrated no detectable binding of VEGF Trap to human VEGF-C and human VEGF-D, however a positive control binding experiment confirmed the ability of VEGF$\mathrm{C}$ and VEGF-D to associate with VEGFR3 (Online Resource 1, Fig. 5).

\section{KinExA equilibrium assays}

In addition to surface capture kinetic experiments, solution binding studies were also conducted at room temperature $\left(25^{\circ} \mathrm{C}\right)$ using a KinExA 3000 instrument (Sapidyne Instruments, Boise, ID) to quantify the equilibrium binding constants of VEGF inhibitors in solution, using varying concentrations of VEGF-A $\mathrm{A}_{165}, \mathrm{VEGF}-\mathrm{A}_{121}, \mathrm{hPlGF}-2$ or VEGF-B $_{(10-108)}$. Inhibitor-ligand mixtures were equilibrated at room temperature for 10-96 h. Fifty microgram of human VEGF-A $\mathrm{A}_{165}$ was immobilized onto $75 \mathrm{mg}$ Azlactone beads, suspended in $1.5 \mathrm{ml}$ PBS and rotated at $4^{\circ} \mathrm{C}$ overnight. The supernatant was removed and the beads were incubated for another hour at room temperature in $1.0 \mathrm{ml}$ PBS with $10 \mathrm{mg} / \mathrm{ml}$ BSA to block nonspecific binding sites. The blocked beads were washed three times with PBS, resuspended in $30 \mathrm{ml}$ of PBS, and used immediately. Co-complex mixtures contained: VEGF Trap (concentration range 1-50 pM) with VEGF-A ${ }_{165}$ or VEGF$\mathrm{A}_{121}$ (concentration range $19.5 \mathrm{fM}-100 \mathrm{pM}$ ) or hPLGF-2 (concentration range $0.5 \mathrm{pM}-5 \mathrm{nM}$ ) or VEGF-B ${ }_{(10-108)}$ (concentration range $0.61 \mathrm{pM}-1.25 \mathrm{nM}$ ): Ranibizumab (concentration range 50-400 pM) with VEGF-A 165 (concentration range $0.73 \mathrm{pM}-15 \mathrm{nM}$ ): Bevacizumab (concentration range $25-50 \mathrm{pM}$ ) with VEGF- $\mathrm{A}_{165}$ (concentration range $0.49 \mathrm{pM}-5 \mathrm{nM}$ ). Human VEGF- $\mathrm{A}_{165}$ was coupled to Azlactone beads and was used to capture unbound inhibitor. Equilibrated mixtures were injected through a column of VEGF-A ${ }_{165}$-coupled micro-beads in the KinExA system at a flow rate of $0.25 \mathrm{ml} / \mathrm{min}$. Bead contact time was $<0.5 \mathrm{~s}$, permitting unbound VEGF inhibitors to be captured by the beads without perturbing the equilibrium state of the solution. Captured VEGF inhibitors were quantified with Cy5-conjugated goat polyclonal antihuman $\operatorname{IgG}$ or anti-human $\mathrm{F}\left(\mathrm{ab}^{\prime}\right)_{2}$ fragment specific for light-chain antibody (Jackson ImmunoResearch Laboratories, West Grove, PA). The $K_{\mathrm{D}}$ was obtained from nonlinear regression analysis of the data using a one-site homogeneous binding model contained within the KinExA software (Version 1.0.3; Sapidyne Instruments) using the 'standard analysis' method. The software calculates the $K_{\mathrm{D}}$ and determines the $95 \%$ confidence interval by fitting the data points to a theoretical $K_{\mathrm{D}}$ curve (Online Resource 1,
Figures 6 and 7). The 95\% confidence interval is given as $K_{\mathrm{D}}$ low and $K_{\mathrm{D}}$ high as described by Darling et al. [43].

Cell-based bioassays

\section{VEGFR1/VEGFR2 cell lines and VEGF assay}

In order evaluate the ability of VEGF Trap, ranibizumab and bevacizumab to specifically block ligand-mediated dimerization and activation of VEGFR1 or VEGFR2, two separate cell lines expressing these receptors were created. Two chimeric VEGFR1 receptors were constructed that incorporated the VEGFR1 extracellular domain (1-756, Genbank \# NP_002010) fused to the transmembrane and cytoplasmic domain of either IL18R $\alpha$ (328-541, Genbank \# NP_003846.1) or IL18R $\beta$. 355-549, Genbank \# NP_003844.1). The VEGFR1/IL18R $\alpha$ chimeric receptor was cloned into a plasmid with a G418 resistance marker, while the VEGFR1/IL18R $\beta$ chimeric receptor was cloned into a plasmid with a hygromycin resistance marker. The chimeric receptors were transfected into an HEK293 cell line with an integrated NF $\kappa \mathrm{B}$-luciferase-IRES-eGFP reporter gene using Lipofectamine plus (Invitrogen, Carlsbad, CA) according to manufacturer's instructions. Likewise, similar chimeric receptors incorporating the VEGFR2 extracellular domain (1-764, Genbank \# NP_002244.1) fused to the transmembrane and cytoplasmic domain of either IL18R $\alpha$ or IL18R $\beta$ were constructed and transfected into the same HEK293 reporter cell line. In order to isolate cells for use in a bioassay, the cells were grown in G418 (Invitrogen, Inc.) and hygromycin (Calbiochem) to ensure the presence of both chimeric receptors. Cells underwent further selection by stimulating the cells with VEGF and then sorting cells expressing GFP by fluorescence activated cell sorting (FACS). When the extracellular VEGFR1 or VEGFR2 is dimerized by binding VEGF, the IL18R $\alpha$ and $\beta$ intracellular domains interact and are able to signal through the $\mathrm{NF} \kappa \mathrm{B}$ driven luciferase reporter gene.

\section{VEGF and PIGF activation of the VEGFR1 and VEGFR2} cell lines

Cells expressing either VEGFR1 or VEGFR2 were resuspended at $1.25 \times 10^{5}$ cells $/ \mathrm{ml}$ in Optimem (Invitrogen, Inc.) plus $0.1 \%$ fetal calf serum (FCS) and $80 \mu \mathrm{l}$ was placed in each well of a 96 well plate $(10,000$ cells/well). The cells were incubated overnight at $37^{\circ} \mathrm{C}, 5 \% \mathrm{CO}_{2}$. The dose response curve for VEGFR1 activation was determined by adding $20 \mu \mathrm{l}$ of VEGF-A $\mathrm{A}_{165}$, VEGF- $\mathrm{A}_{121}$ or PlGF-2 (human or mouse) to the cells at concentrations ranging from $0.022 \mathrm{pM}$ to $4.0 \mathrm{nM}$. One well served as the negative control with no test ligand added. The dose 
response curve for VEGFR2 activation was determined by adding $20 \mu \mathrm{l}$ of VEGF-A $\mathrm{A}_{165}, \mathrm{VEGF}-\mathrm{A}_{121}$, or $\mathrm{hPIGF}-2$ to the cells at the same concentrations used above. Each dose response curve was done in quadruplicate. After addition of the VEGF or PlGF, the plates were incubated at $37^{\circ} \mathrm{C}$ and $5 \% \mathrm{CO}_{2}$ for $6 \mathrm{~h}$, and then equilibrated to room temperature for $30 \mathrm{~min}$. An equal volume of One-glo luciferase substrate (Promega, Madison, WI) was added to each well and the plate was incubated at room temperature for a further 15 min. Plates were read on Victor $X$ instrument and the values were analyzed by a four-parameter logistic equation over a 12-point dose response curve (Prism, GraphPad Software, version 5.03, La Jolla, CA).

VEGF Trap, bevacizumab and ranibizumab were tested with both the VEGFR1 and VEGFR2 cell lines. VEGF Trap was added to the cells at concentrations ranging from $0.8 \mathrm{pM}$ to $50 \mathrm{nM}$ and included a control well with buffer. Bevacizumab and ranibizumab were added to the cells at concentrations ranging from $8.5 \mathrm{pM}$ to $500 \mathrm{nM}$ and included a control well. Immediately after addition of VEGF Trap or the antibodies to the VEGFR1 cell line, VEGF-A 165 , VEGF-A 121 , or hPlGF-2 was added to the cells at a constant concentration of $20 \mathrm{pM}$ (VEGF) or $40 \mathrm{pM}$ (hPIGF-2). The VEGFR2 cell line was stimulated with $20 \mathrm{pM}$ VEGF-A $\mathrm{A}_{165}$ or $20 \mathrm{pM}$ VEGF-A $\mathrm{A}_{121}$. The plates were incubated at $37^{\circ} \mathrm{C}$ and $5 \% \mathrm{CO}_{2}$ for $6 \mathrm{~h}$ and then equilibrated to room temperature for $30 \mathrm{~min}$. An equal volume of One-glo luciferase substrate (Promega) was added to each well and the plate was incubated at room temperature for a further $15 \mathrm{~min}$. Plates were read on Victor $\mathrm{X}$ instrument and the values were analyzed by a four-parameter logistic equation over a 12-point response curve (GraphPad Prism). Each inhibition curve was done in triplicate.

\section{VEGF dependent calcium mobilization in human umbilical vein endothelial cells (HUVEC)}

HUVEC (Vec Technologies, Inc., Rensselaer, NY) were diluted to $3 \times 10^{5}$ cells $/ \mathrm{ml}$ in MCDB-131 complete medium (Vec Technologies, Inc.), and $100 \mu \mathrm{l}$ was added to each well of a 96 well plate. The plates were incubated overnight at $37^{\circ} \mathrm{C}$ and $5 \% \quad \mathrm{CO}_{2}$. The media was then removed and the HUVEC loaded with a calcium sensitive dye, Fluo4 NW (Invitrogen, Inc), in ECB media (BD Biosciences) with $0.25 \mathrm{mM}$ of probenicid and $0.3 \%$ BSA (80 $\mu$ l per well). The solution was incubated with the cells for $30 \mathrm{~min}$ at $37^{\circ} \mathrm{C}$ and $5 \% \mathrm{CO}_{2}$ followed by another $30 \mathrm{~min}$ at room temperature.

To measure the dose response, HUVEC were simulated with buffer or VEGF-A 165 at concentrations ranging from $0.023 \mathrm{pM}$ to $4.0 \mathrm{nM}$. The cellular response was recorded at a fluorescence emission wavelength of $575 \mathrm{~nm}$ with an excitation of $515 \mathrm{~nm}$ for $6 \mathrm{~min}$, using the FLIPR $^{\text {TETRA }}$ (Molecular Devices, Sunnyvale, CA). Each dose response curve was done in duplicate.

Inhibition of VEGF-A $A_{165}$ was determined by adding VEGF Trap at concentrations ranging from $0.17 \mathrm{pM}$ to $10.0 \mathrm{nM}$ and for bevacizumab and ranibizumab at concentrations ranging from $8.4 \mathrm{pM}$ to $500 \mathrm{nM}$. VEGF Trap, bevacizumab, or ranibizumab were incubated with $20 \mathrm{pM}$ VEGF-A $\mathrm{A}_{165}$ for $10 \mathrm{~min}$ and then added to the cells, and the calcium response recorded as above. The data were analyzed using the average peak fluorescence at each inhibitor concentration tested in triplicate.

Cell migration assays

\section{Cell culture}

HUVEC, at first passage, were purchased from VEC Technologies and grown at $37^{\circ} \mathrm{C}$ in a $5 \% \mathrm{CO}_{2}$ humidified incubator, in MCDB-131 complete media. Cells grown to confluency in $10 \mathrm{~cm}^{2}$ culture dishes, were washed twice with Hank's Buffered Saline Solution (HBSS; Mediatech, Manassas, VA.) without calcium, magnesium or phenol red, and dissociated with Trypsin/EDTA (Lonza, Walkersville, MD). Cells were then seeded at approximately $2 \times 10^{5}$ cells/dish and typically reached confluency in 3-4 days. Prior to use in cell migration assays, cells were serum-starved for $5 \mathrm{~h}$ in MCDB-131 basal media (MBM; VEC Technologies) supplemented with $2 \mathrm{mM}$ L-glutamine, $100 \mathrm{U} / \mathrm{ml}$ Penicillin, $100 \mu \mathrm{g} / \mathrm{ml}$ Streptomycin, $10 \mu \mathrm{g} / \mathrm{ml}$ heparin, and $0.1 \%$ fetal bovine serum.

\section{HUVEC migration}

HUVEC migration was assessed using a modified Boyden chamber [BD FluoroBlok ${ }^{\mathrm{TM}}$ 24-well Biocoat angiogenesis system: Endothelial cell migration (ECM); $3 \mu \mathrm{m}$ pore size] according to the manufacturer's suggested protocol. Briefly, serum-starved HUVECs were dissociated using enzyme-free cell dissociation media (Millipore, Billerica, MA) and resuspended in MBM to a final concentration of 2-3 $310^{5}$ cells $/ \mathrm{ml}$. An aliquot of resuspended cells (250 $\mu \mathrm{l}$; $\sim 50,000$ cells/well) was placed in the upper well of the ECM plate, and MBM $(750 \mu \mathrm{l})$ with or without ligand (130 pM human VEGF-A $165,7.1 \mathrm{nM}$ human PLGF2, or $3.5 \mathrm{nM}$ mouse PLGF-2), was mixed with VEGF Trap, bevacizumab, or ranibizumab (inhibitor concentration range $0.013-13 \mathrm{nM}$ ) and placed in the lower well following a $1 \mathrm{~h}$ incubation of the mixture at room temperature. The ECM plate was incubated for $18-20 \mathrm{~h}$ in a $37^{\circ} \mathrm{C} / 5 \%$ $\mathrm{CO}_{2}$ incubator to allow cells from the upper well to migrate through the FluoroBlok ${ }^{\mathrm{TM}}$ membrane towards the lower well. Following migration, cells attached to the underside 
of the FluoroBlok ${ }^{\mathrm{TM}}$ membrane were stained with $500 \mu \mathrm{L}$ of a $2 \mu \mathrm{g} / \mathrm{mL}$ solution of the fluorescent dye Calcein AM (Anaspec, Freemont, CA) for $1.5 \mathrm{~h}$ in a $37^{\circ} \mathrm{C} / 5 \% \mathrm{CO}_{2}$ incubator. Fluorescence emission was measured at $580 \mathrm{~nm}$ with excitation at $485 \mathrm{~nm}$ in a Flexstation 3 (Molecular Devices, Sunnyvale CA) bottom-reading fluorescent plate reader. Statistical analyses were carried out using a 1-way ANOVA followed by a Dunnett's multiple comparison post hoc test (Prism, GraphPad Software, version 5.03, La Jolla, CA).

\section{Results}

VEGF Trap binds VEGF-A, VEGF-B and PIGF from multiple species with high affinity

The interaction between VEGF Trap and VEGF family ligands was measured using SPR-Biacore technology. Kinetic binding data was generated using an amine-coupled Protein A surface and subsequent VEGF Trap capture at low density. VEGF Trap bound heparin binding and nonheparin binding isoforms of human VEGF-A, and PIGF, as well as VEGF-B $\mathrm{B}_{(10-108)}$ with high affinity (Table 1 and Online Resource 1, Table 1). Notably, the equilibrium dissociation constant $\left(K_{\mathrm{D}}\right)$ of VEGF Trap for VEGF-A 165 $(0.490 \mathrm{pM})$ was significantly lower (tighter binding) than that of the extracellular domains of dimerized human VEGFR1 (9.33 pM) or VEGFR2 (88.8 pM) fused inline to $\mathrm{hFc}$ (Table 1 and Online Resource 1, Fig. 5). The above absolute and relative $K_{\mathrm{D}}$ values for VEGFR1-Fc and VEGFR2-Fc are comparable to those previously reported for native VEGFR1 and VEGFR2 using cell-based bindings assays [44, 45]. VEGF Trap did not bind human VEGF-C or human VEGF-D (Online Resource 1, Fig. 5). The $K_{\mathrm{D}}$ values for the interaction between VEGF Trap and VEGF-A from mouse, rat and rabbit were similar to those of human and ranged from 0.471 to $0.776 \mathrm{pM}$. VEGF Trap also bound human and murine PlGF-2 with a $K_{\mathrm{D}}$ of 38.9 and $3.32 \mathrm{pM}$, respectively (Table 1 and Online Resource 1, Table 1). In contrast, bevacizumab and ranibizumab are specific for human and non-human primate VEGF-A, and do not effectively bind or neutralize rodent VEGF [46-48].

Binding parameters for VEGF Trap, ranibizumab and bevacizumab interactions with human VEGF-A $\mathrm{A}_{165}$ and PlGF-2

While all three VEGF inhibitors bound human VEGF- $\mathrm{A}_{165}$ with high affinity, the $K_{\mathrm{D}}$ for VEGF Trap binding of VEGF-A $A_{165}$ was approximately 100 -fold lower (i.e. the binding affinity was $\sim 100$-fold tighter) than that for ranibizumab or bevacizumab (Table 1). Specifically, the $K_{\mathrm{D}}$ value for VEGF Trap was $0.490 \mathrm{pM}$, while those for ranibizumab and bevacizumab were 46 and $58 \mathrm{pM}$, respectively. The lower $K_{\mathrm{D}}$ value for VEGF Trap binding VEGF-A $A_{165}$ was primarily attributable to a significantly faster association rate $\left(k_{\mathrm{a}}\right)$ that was 77 - and 256 -fold faster than that for bevacizumab and ranibizumab, respectively (Table 1). VEGF Trap also bound human PlGF-2 with high affinity $\left(K_{\mathrm{D}}=38.9 \mathrm{pM}\right)$, whereas no binding was detected between ranibizumab or bevacizumab and human PlGF-2 (Table 1). Biacore kinetic sensorgrams analyzed for association and dissociation rate constants are provided in Online Resource 1, Figures 1-4.

To confirm the surface kinetic data determined using SPR-Biacore, the binding interactions between soluble VEGF Trap, bevacizumab or ranibizumab and human VEGF-A $A_{165}$ were also compared in solution equilibrium assays using KinExA methodology. As shown in Table 2 and Online Resource 1, Figures 6 and 7, the absolute $K_{\mathrm{D}}$ values and $95 \%$ confidence interval obtained for the VEGF inhibitors binding to VEGF- $\mathrm{A}_{165}$, were comparable to those obtained with SPR-based measurements. Similarly, VEGF Trap binding affinities for VEGF- $\mathrm{A}_{121}$, VEGF-B (10-108), and PlGF were also comparable between SPR and solution based equilibrium assays.

Effects of VEGF Trap, ranibizumab and bevacizumab on VEGF-A or PIGF-2 induced activation of VEGFR1

To determine the ability of VEGF Trap, ranibizumab and bevacizumab to block human VEGF-A or PIGF-2 induced VEGFR1 activation in vitro, a VEGFR1 specific luciferase assay was developed, which used the human cell line HEK293 transfected with an $\mathrm{NF} \kappa \mathrm{B}$-luciferase reporter plasmid and human VEGFR1 (Fig. 1). Notably in this assay, the potency of ranibizumab for blocking $20 \mathrm{pM}$ VEGF- $A_{121}$ or VEGF- $A_{165}$ induced luciferase activity through VEGFR1 was only slightly greater than that of bevacizumab. Ranibizumab exhibited $\mathrm{IC}_{50}$ values $(50 \%$ inhibitory concentration) of 675 and $1,140 \mathrm{pM}$, while $\mathrm{IC}_{50}$ values for bevacizumab were 845 and $1,476 \mathrm{pM}$ for VEGF-A $_{121}$ or VEGF-A $A_{165}$, respectively. In contrast, VEGF Trap exhibited a 45-92-fold greater blocking potency compared to either ranibizumab or bevacizumab, with $\mathrm{IC}_{50}$ values of 15 and $16 \mathrm{pM}$ for blocking VEGFR1 activation by $20 \mathrm{pM}$ VEGF-A $\mathrm{A}_{121}$ or VEGF- $\mathrm{A}_{165}$, respectively (Table 3; Fig. 1). VEGF Trap also blocked luciferase activity induced by human PLGF-2 (40 pM) or mouse PlGF-2 (20 pM) with $\mathrm{IC}_{50}$ values of $2.9 \mathrm{nM}$ and $104 \mathrm{pM}$, respectively. In contrast, neither bevacizumab nor ranibizumab showed ability to block human or mouse PlGF-2 under these experimental conditions. 
Table 1 Kinetic binding parameters for VEGF Trap, ranibizumab and bevacizumab binding to human VEGF family ligands determined by SPR-Biacore

\begin{tabular}{|c|c|c|c|c|}
\hline \multirow{2}{*}{$\begin{array}{l}\text { VEGF } \\
\text { inhibitor }\end{array}$} & \multirow[t]{2}{*}{ Ligand } & \multicolumn{3}{|c|}{ Kinetic binding parameters } \\
\hline & & $\begin{array}{l}k_{\mathrm{a}} / 10^{5} \\
\left(\mathrm{M}^{-1} \mathrm{~s}^{-1}\right)\end{array}$ & $\begin{array}{l}k_{\mathrm{d}} / 10^{-5} \\
\left(\mathrm{~s}^{-1}\right)\end{array}$ & $\begin{array}{l}K_{\mathrm{D}} \\
(\mathrm{pM})\end{array}$ \\
\hline VEGF Trap ${ }^{a}$ & VEGF-A $A_{121}$ & $375.0(5.0)$ & $1.35(.02)$ & 0.360 \\
\hline VEGF Trap ${ }^{a}$ & VEGF-A 165 & $410.0(10.0)$ & $2.01(.01)$ & 0.490 \\
\hline Ranibizumab $^{\mathrm{b}}$ & VEGF-A 165 & $1.6(0.003)$ & $0.73(.005)$ & 46 \\
\hline Bevacizumab $^{\mathrm{a}}$ & VEGF-A 165 & $5.3(0.01)$ & $3.10(.02)$ & 58 \\
\hline hVEGFR1-Fc ${ }^{a}$ & VEGF-A 165 & $300.0(20.0)$ & $28.0(1.0)$ & 9.33 \\
\hline hVEGFR2-Fc ${ }^{a}$ & VEGF-A 165 & $152.0(5.0)$ & $135(6.0)$ & 88.8 \\
\hline VEGF Trap $^{\mathrm{a}}$ & PlGF-2 & $17.5(0.06)$ & $6.81(.03)$ & 38.9 \\
\hline Ranibizumab $^{\text {b }}$ & PlGF-2 & NB & NB & NB \\
\hline Bevacizumab $^{\mathrm{a}}$ & PIGF-2 & NB & NB & NB \\
\hline VEGF Trap ${ }^{a}$ & VEGF-B $_{(10-108)}$ & $352.0(3.0)$ & $6.74(.09)$ & 1.92 \\
\hline
\end{tabular}

Numbers in parentheses represent the standard error of the kinetic fit $N B$ No binding under assay conditions used

${ }^{a}$ VEGF inhibitor captured on a Protein A-coupled sensor chip

b VEGF inhibitor captured on an anti-human Fab polyclonal antibody-captured sensor chip

Table 2 Solution binding parameters for VEGF Trap, ranibizumab and bevacizumab binding to human VEGF family ligands determined by KinExA equilibrium assays

\begin{tabular}{llll}
\hline VEGF inhibitor & Ligand & \multicolumn{2}{l}{$\begin{array}{l}\text { Kinexa equilibrium binding } \\
\text { parameters }\end{array}$} \\
\cline { 3 - 4 } & & $K_{\mathrm{D}}(\mathrm{pM})$ & $K_{\mathrm{D}}$ range $(\mathrm{pM})^{\mathrm{a}}$ \\
\hline VEGF Trap & VEGF-A $_{165}$ & 0.66 & $0.36-1.06$ \\
Ranibizumab & VEGF-A $_{165}$ & 20.6 & $10.9-36.3$ \\
Bevacizumab & VEGF-A $_{165}$ & 35.1 & $12.2-82.9$ \\
VEGF Trap & VEGF-A $_{121}$ & 0.18 & $0.08-0.32$ \\
VEGF Trap & PlGF-2 $_{2}$ & 20.7 & $13.7-29.3$ \\
VEGF Trap & VEGF-B $_{(10-108)}$ & 17.5 & $12.9-22.9$ \\
\hline
\end{tabular}

a $95 \%$ confidence interval

Effects of VEGF Trap, ranibizumab and bevacizumab on VEGF-A induced activation of VEGFR2

To determine the ability of VEGF Trap, ranibizumab and bevacizumab to block VEGFR2 activation in vitro, a VEGFR2 specific luciferase assay was developed, which used the human cell line HEK293 transfected with an $\mathrm{NF} \kappa \mathrm{B}$-luciferase reporter plasmid and human VEGFR2 (Fig. 2). As for VEGFR1, VEGF Trap efficiently blocked VEGFR2 signaling induced by $20 \mathrm{pM}$ of human VEGF$\mathrm{A}_{121}$ or VEGF-A $\mathrm{A}_{165}\left(\mathrm{IC}_{50}\right.$ of 16 and $26 \mathrm{pM}$, respectively).
VEGF Trap was again markedly more potent in blocking VEGF-mediated VEGFR2 activation than either ranibizumab or bevacizumab (33-51-fold more potent, see Fig. 2; Table 3). As expected, hPlGF-2 was not able to activate VEGFR2 in this assay.

The effect of VEGF Trap, ranibizumab and bevacizumab on VEGF- $\mathrm{A}_{165}$ induced calcium mobilization in human endothelial cells

The ability of the three VEGF inhibitors to block human VEGF- $_{165}$ induced activation of VEGF receptors was also tested in human endothelial cells. A VEGF- $\mathrm{A}_{165}$ induced calcium mobilization assay was developed using HUVEC [49, 50], which express native VEGFR1 and VEGFR2 (Fig. 3). Interestingly in this assay, bevacizumab was $\sim 5$ fold more potent than ranibizumab at blocking VEGF- $\mathrm{A}_{165}$ induced calcium mobilization. Nevertheless, the $\mathrm{IC}_{50}$ for VEGF Trap was $\sim 27$-fold lower than that of bevacizumab and $\sim 129$-fold lower than ranibizumab, confirming the greater potency of VEGF Trap for blocking VEGFR1 and VEGFR2 activation in vitro (Table 3; Fig. 3). The relative potency of VEGF blockers in this acute assay may reflect differences in their association rate constants.

The effect of VEGF Trap, bevacizumab

and ranibizumab on HUVEC migration induced by $\mathrm{VEGF}_{165}$ or PlGF-2

Endothelial cell migration plays a central part in the process of angiogenesis and, consistent with its pro-angiogenic profile, VEGF acts as a chemoattractant for endothelial cells [51]. To determine the ability of VEGF Trap, ranibizumab and bevacizumab to block human VEGF-A $\mathrm{A}_{165}$ induced cell migration, HUVEC mobility was assessed in a modified Boyden chamber assay. None of the VEGF inhibitors affected basal endothelial cell migration in the absence of test ligands (data not shown). In the presence of VEGF-A $_{165}(130 \mathrm{pM})$, VEGF Trap blocked VEGF-A 165 induced cell migration in a dose-dependent manner (Fig. 4). At a 1:1 molar ratio of VEGF Trap and VEGF-A ${ }_{165}$, cell migration was reduced by approximately $90 \%$. Ranibizumab and bevacizumab also inhibited cell migration in a dosedependent manner (Fig. 4) but were less potent than VEGF Trap, requiring a 10- to 100-fold greater molar concentration of inhibitor to produce an equivalent level of inhibition of cell migration due to VEGF- $\mathrm{A}_{165}$ activation.

PIGF also acts as a chemoattractant for endothelial cells through VEGFR1 [52]. Again, the modified Boyden chamber assay was used to test the ability of the VEGF inhibitors to block HUVEC migration stimulated by human PlGF-2. As shown in Fig. 4 (inset), a 100-fold excess of VEGF Trap blocked cell migration induced by human 

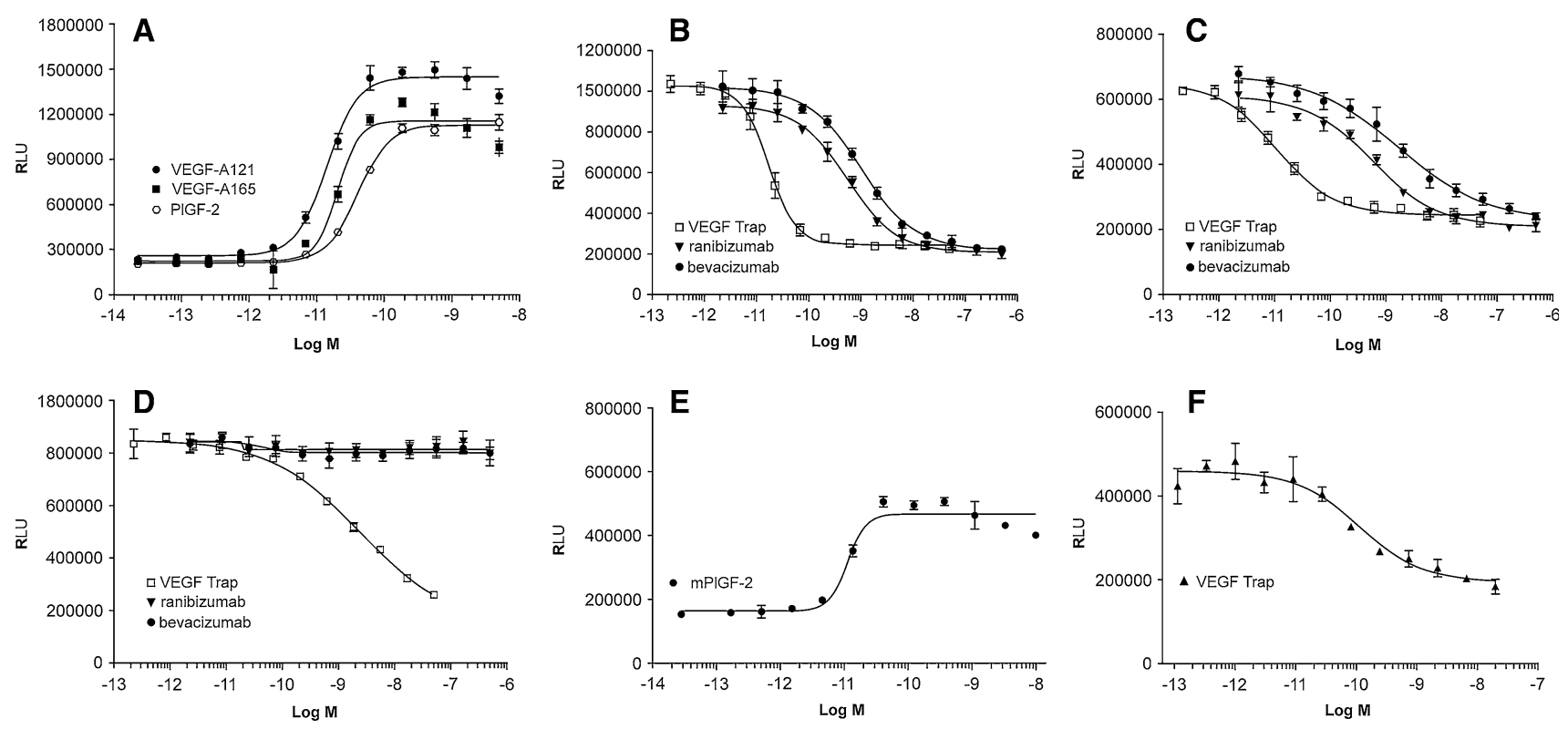

Fig. 1 The effects of VEGF Trap, ranibizumab and bevacizumab on luciferase activation induced by VEGF-A $A_{121}$, VEGF-A $A_{165}$, human PlGF-2 (hPlGF-2) or mouse PlGF-2 (mPLGF-2) in HEK293/VEGFR1 cells. a Dose response curves for VEGF-A 121 , VEGF-A $A_{165}$ and hPlGF-2 yielded $\mathrm{EC}_{50}$ values of 13,17 , and $29 \mathrm{pM}$, respectively. b Serial dilutions of VEGF Trap (open box), ranibizumab (triangle), or bevacizumab (closed circle) were added to HEK293/VEGFR1 cells along with 20 pM of VEGF-A ${ }_{121}$. c Serial dilutions of VEGF Trap (open box), ranibizumab (triangle), or bevacizumab (closed circle) were added to HEK293/VEGFR1 cells along with 20 pM of VEGF-
$\mathrm{A}_{165}$. d Serial dilutions of VEGF Trap (open box), ranibizumab (triangle), or bevacizumab (closed circle) were added to HEK293/ VEGFR1 cells along with $40 \mathrm{pM}$ of human PIGF-2. e Dose response curve for mPlGF-2 yielded an $\mathrm{EC}_{50}$ value of $10 \mathrm{pM}$ (f). Serial dilutions of VEGF Trap were added to HEK293/VEGFR1 cells along with $20 \mathrm{pM}$ of mPIGF-2. The cells were incubated for $6 \mathrm{~h}$ and OneGlo luciferase substrate was then added to each well. The plates were read on a luminometer and the data were plotted using a four parameter curve fit with GraphPad Prism. Each point represents a replica of 3 wells at each concentration

Table 3 Summary of $\mathrm{IC}_{50}$ values for VEGF Trap, ranibizumab and bevacizumab blocking VEGF-A or PlGF-2 induced activation of VEGFR1 and VEGFR2

\begin{tabular}{|c|c|c|c|c|c|c|c|}
\hline \multirow[t]{2}{*}{ VEGF inhibitor } & \multicolumn{4}{|c|}{ VEGFR1 cell line } & \multicolumn{2}{|c|}{ VEGFR2 cell line } & \multirow{2}{*}{$\begin{array}{l}\mathrm{Ca}^{2+} \text { mobilization } \\
\text { in } \mathrm{HUVE} \text { cells } \\
\mathrm{IC}_{50} \text { at } 20 \mathrm{pM} \\
\text { hVEGF-A }_{165}\end{array}$} \\
\hline & $\begin{array}{l}\mathrm{IC}_{50} \text { at } 20 \mathrm{pM} \\
\text { hVEGF-A } \\
121\end{array}$ & $\begin{array}{l}\mathrm{IC}_{50} \text { at } 20 \mathrm{pM} \\
\text { hVEGF-A } \\
165\end{array}$ & $\begin{array}{l}\mathrm{IC}_{50} \text { at } 40 \mathrm{pM} \\
\text { hPlGF-2 }\end{array}$ & $\begin{array}{l}\mathrm{IC}_{50} \text { at } 20 \mathrm{pM} \\
\text { mPlGF-2 }\end{array}$ & $\begin{array}{l}\mathrm{IC}_{50} \text { at } 20 \mathrm{pM} \\
\text { hVEGF-A } \\
121\end{array}$ & $\begin{array}{l}\mathrm{IC}_{50} \text { at } 20 \mathrm{pM} \\
\text { hVEGF-A } \\
165\end{array}$ & \\
\hline VEGF Trap & 15 pM (2.4) & $16 \mathrm{pM}(2.2)$ & $2,890 \mathrm{pM}(227)$ & 104 pM (23) & 16 pM (2.5) & $26 \mathrm{pM}(11)$ & $2.6 \mathrm{pM}(1.2)$ \\
\hline Ranibizumab & 675 pM (165) & $1,140 \mathrm{pM}(226)$ & NB & NB & 576 pM (84) & 845 pM (185) & $334.9 \mathrm{pM}(61.1)$ \\
\hline Bevacizumab & 854 pM (214) & $1,476 \mathrm{pM}(288)$ & NB & NB & $630 \mathrm{pM}(66)$ & $1,323 \mathrm{pM}(491)$ & 70.8 pM (20.1) \\
\hline
\end{tabular}

Numbers in parentheses represent standard error of the mean

The $\mathrm{IC}_{50}$ numbers were obtained from at least 3 separate experiments

hVEGF: human VEGF; hPlGF-2: human PIGF-2; mPLGF-2: mouse PIGF-2

$N B$ No blocking activity observed under the assay conditions used

PlGF-2 (7.1 nM) or mouse PlGF-2 (3.5 nM) by approximately $80 \%$. In contrast, ranibizumab and bevacizumab did not inhibit cell migration induced by either human or mouse PIGF-2.

\section{Discussion}

The experiments described herein provide a comprehensive assessment of the ability of VEGF Trap, ranibizumab and bevacizumab to bind and block the activity of VEGF family ligands in vitro, under identical experimental conditions. The data demonstrate that VEGF Trap binds human VEGFA with higher affinity and a significantly faster association rate, thus neutralizing VEGF-A with greater potency than ranibizumab or bevacizumab. In addition, the studies show that VEGF Trap has the unique ability to bind the additional VEGF family ligands, VEGF-B and PIGF. Moreover, VEGF Trap also bound VEGF-A and PlGF isoforms from all mammalian species tested with similar high affinity, while neither ranibizumab nor bevacizumab efficiently bind and neutralize mouse or rat VEGF-A [46-48]. 

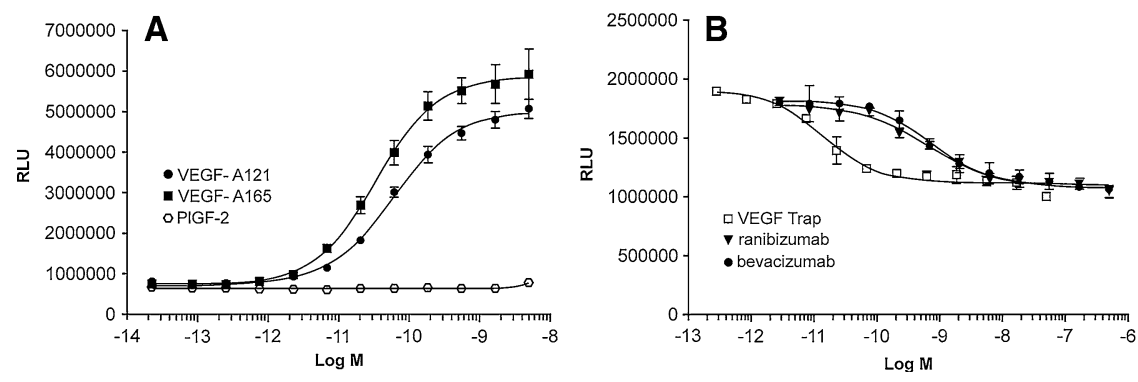

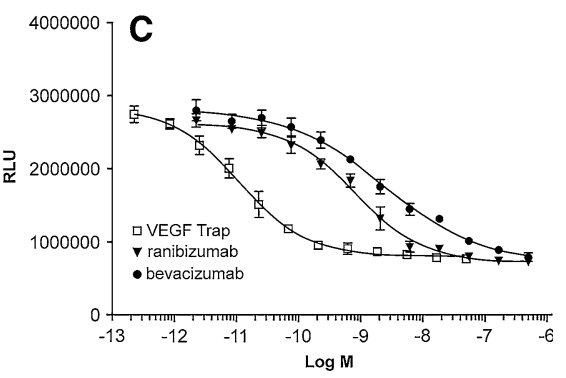

Fig. 2 The effects of VEGF Trap, ranibizumab and bevacizumab on luciferase activation induced by VEGF- $\mathrm{A}_{121}$ and VEGF- $\mathrm{A}_{165}$ in HEK293/VEGFR2 cells. a Dose response curves for VEGF-A $A_{121}$ and VEGF- $\mathrm{A}_{165}$ with $\mathrm{EC}_{50}$ values of 70 and $30 \mathrm{pM}$, respectively. PlGF-2 was not active in this assay. $\mathbf{b}$ Serial dilutions of VEGF Trap (open box), ranibizumab (triangle) or bevacizumab (closed circle) were added to HEK293/VEGFR2 cells along with 20 pM of VEGF-A 121 $_{1}$. c Serial dilutions of VEGF Trap (open box), ranibizumab (triangle) or bevacizumab (closed circle) were added to HEK293/VEGFR2 cells along with $20 \mathrm{pM}$ of VEGF-A 165 . The cells were incubated for $6 \mathrm{~h}$ and OneGlo luciferase substrate was then added to each well. The plates were read on a luminometer and the data were plotted using a four parameter curve fit with GraphPad Prism. Each point represents a replica of 3 wells at each concentration

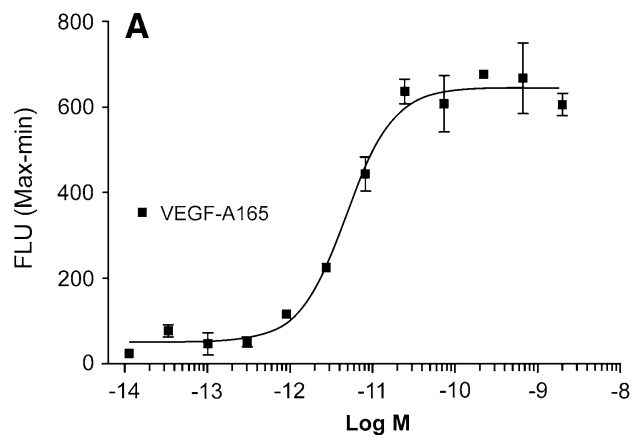

Fig. 3 The effects of VEGF Trap, ranibizumab and bevacizumab on calcium mobilization induced byVEGF-A 165 in HUVEC. a A doseresponse curve generated using serial dilutions of VEGF-A 165 $(4.0 \mathrm{nM}-0.023 \mathrm{pM})$ resulted in an $\mathrm{EC}_{50}$ value of $5 \mathrm{pM}$. b Serial dilutions of VEGF Trap (open box), ranibizumab (triangle) or bevacizumab (closed circle) were added to HUVEC along with

Several published papers have provided binding affinity data for ranibizumab's interactions with human VEGF-A $[28,36,37]$. However, to date, binding affinity and specificity data have been provided only for the monovalent Fab fragment of bevacizumab (Fab-12), and not the full bivalent bevacizumab molecule itself. The equilibrium dissociation constant $\left(K_{\mathrm{D}}\right)$ for Fab-12 has been variously reported as $1.8 \mathrm{nM}$ [36] or $20 \mathrm{nM} \mathrm{[28],} \mathrm{indicating} \mathrm{an}$ affinity improvement of ranibizumab over Fab-12 of 10-100-fold. Likewise, ranibizumab has been reported to be $30-100$-fold more potent than Fab-12 in bioassays measuring VEGF-induced endothelial cell mitogenesis [26]. However, measuring the kinetic binding parameters or in vitro activity of the Fab-12 fragment does not take into account potential avidity interactions of bivalent antibodies, especially when the binding partner is a dimeric ligand such as VEGF-A. These types of avidity driven interactions can significantly increase binding affinity, and potentially the potency of the bivalent antibody relative to

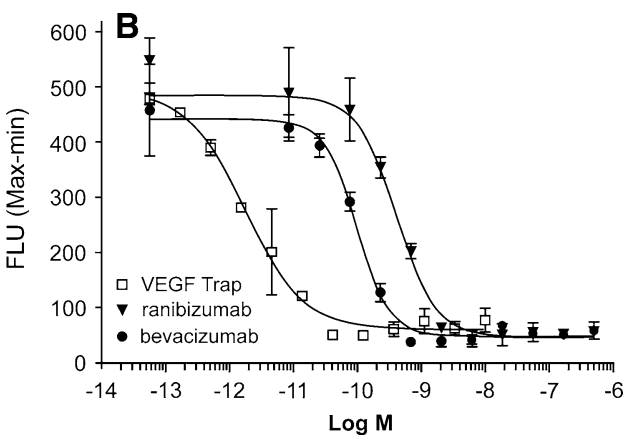

$20 \mathrm{pM}$ of VEGF-A $\mathrm{A}_{165}$. The VEGF-A $\mathrm{A}_{165}$ was preincubated with the inhibitors for $10 \mathrm{~min}$ at $25^{\circ} \mathrm{C}$. The solution was added to HUVEC preloaded with fluo- 4 and the fluorescence of the well was determined on a FLIPR instrument. The data were plotted using a four parameter curve fit with GraphPad Prism. Each point represents duplicate wells at each concentration

that of the monovalent antigen binding fragment in cellbased assays and in vivo.

In the present study, Biacore and KinExA analyses have demonstrated that the equilibrium dissociation constants for VEGF Trap binding VEGF- $\mathrm{A}_{121}$ and VEGF- $\mathrm{A}_{165}$, were less than $1 \mathrm{pM}$, in close agreement with earlier reports [34]. In contrast, ranibizumab exhibited a $K_{\mathrm{D}}$ of $46 \mathrm{pM}$ for VEGF$\mathrm{A}_{165}$. While this represents an approximately 3-4-fold greater affinity for VEGF-A relative to SPR Biacore values previously reported for ranibizumab $\left(K_{\mathrm{D}} \leq 140 \mathrm{pM}\right.$, [28]; $\leq 179 \mathrm{pM}$, [37]), it is nevertheless an $\sim 94$-fold weaker binding for VEGF-A ${ }_{165}$ relative to VEGF Trap $(0.490 \mathrm{pM})$ (Table 4). Similarly, the $K_{\mathrm{D}}$ of soluble VEGF Trap for VEGF- $\mathrm{A}_{165}$, as determined by KinExA was $0.66 \mathrm{pM}$, while that of ranibizumab was $20.6 \mathrm{pM}$, approximately 30 -fold lower than that of VEGF Trap.

Interestingly, the $K_{\mathrm{D}}$ of bevacizumab for VEGF- $\mathrm{A}_{165}$ as determined by Biacore was $58 \mathrm{pM}$, markedly lower than that reported previously for Fab-12 $[28,36]$ and within 


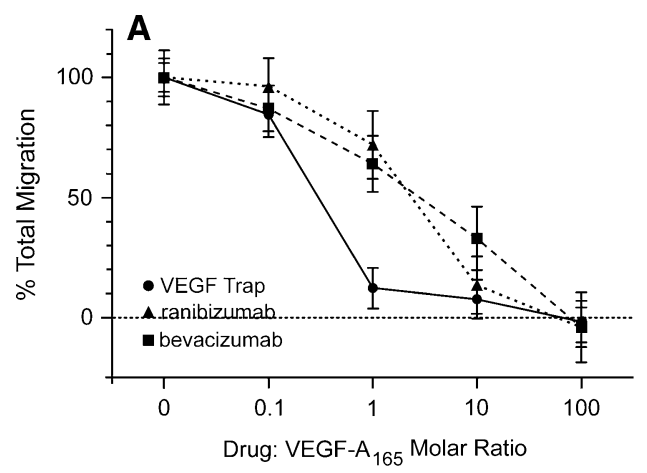

Fig. 4 The effects of VEGF Trap, ranibizumab and bevacizumab on HUVEC migration. a HUVEC were placed in the upper compartment of the Boyden chamber and allowed to migrate towards basal media containing $0.1 \%$ fetal bovine serum with or without VEGF- $A_{165}$ or VEGF-A 165 mixed with four concentrations each of VEGF Trap (circles, solid line), ranibizumab (triangles, dotted line) or bevacizumab (squares, dashed line) ranging from 0.013 to $13 \mathrm{nM}$. The percentage of total migration ( $y$-axis) was calculated as $\left(F_{\text {Drug }}-\right.$ $\left.F_{\text {Basal }}\right) /\left(F_{\text {Total }}-F_{\text {Basal }}\right) \times 100$; where $F_{\text {Total }}$ is fluorescence in the presence of VEGF-A $165, F_{\text {Basal }}$ is fluorescence in the absence of VEGF-A ${ }_{165}$, and $F_{\text {Drug }}$ is fluorescence in the presence of VEGF-A 165 mixed with drug at a specific molar ratio ( $x$-axis). b HUVEC

Table 4 Relative VEGF binding affinities and potency of VEGFR signaling blockade

\begin{tabular}{|c|c|c|c|}
\hline Parameter & Ranibizumab & Bevacizumab & $\begin{array}{l}\text { VEGF } \\
\text { Trap }\end{array}$ \\
\hline $\begin{array}{l}\text { Affinity for VEGF-A } A_{165} \\
\text { (Biacore) }\end{array}$ & 1.0 & 0.79 & 94.0 \\
\hline \multicolumn{4}{|c|}{ Potency of blocking VEGF ( $20 \mathrm{pM})$ mediated signaling } \\
\hline \multicolumn{4}{|l|}{ VEGFR1 } \\
\hline VEGF-A 121 & 1.0 & 0.79 & 45.0 \\
\hline VEGF-A 165 & 1.0 & 0.77 & 71.3 \\
\hline \multicolumn{4}{|l|}{ VEGFR2 } \\
\hline VEGF-A 121 & 1.0 & 0.91 & 36.0 \\
\hline VEGF-A 165 & 1.0 & 0.64 & 32.5 \\
\hline \multicolumn{4}{|l|}{ HUVEC } \\
\hline VEGF-A 165 & 1.0 & 4.73 & 128.8 \\
\hline
\end{tabular}

The relative fold differences for the $K_{\mathrm{D}}$ and $\mathrm{IC}_{50}$ values for bevacizumab and VEGF Trap are expressed relative to values for ranibizumab (set at 1). Higher numbers reflect tighter binding or increased potency in the indicated assays. Raw values used to calculate relative fold differences were taken from Table 1 and Table 3

twofold of the binding affinity of ranibizumab. This was also the case for soluble equilibrium binding of bevacizumab in the Kinexa assay ( $K_{\mathrm{D}}$ of $35.1 \mathrm{pM}$ for bevacizumab and $20.6 \mathrm{pM}$ for ranibizumab), and most likely reflects avidity interactions of the bivalent, full antibody molecule. However, like other conventional antibodies that

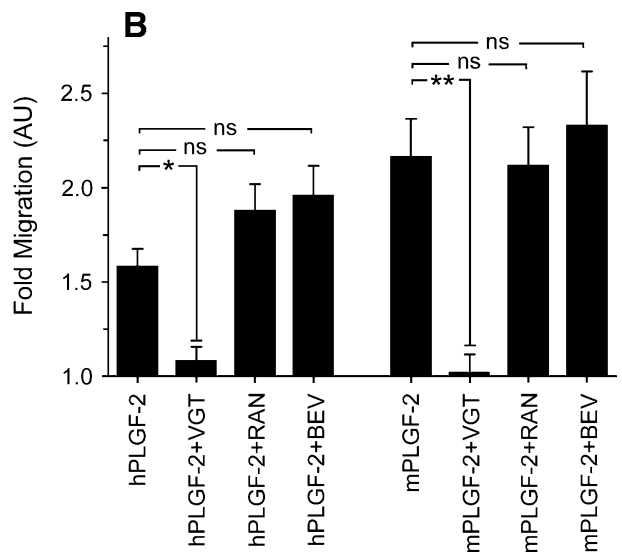

migration was assessed in the absence and presence of human PLGF2 (hPLGF-2) or mouse PLGF-2 (mPLGF-2) with and without a 100-fold molar excess of VEGF Trap (VGT), ranibizumab (RAN) or bevacizumab (BEV). Fold migration ( $y$-axis) was calculated as the ratio $F / F_{\text {Basal }}$; where $F$ is the total fluorescence measured for the indicated condition ( $x$-axis) and $F_{\text {Basal }}$ is the fluorescence in the absence of either hPLGF-2 or mPLGF-2. Statistical significance: $* P<0.05 ; * * P<0.01 ;$ ns, no significance. Values and error bars represent the average value and standard error of the mean from at least three independent experiments with each experiment containing four biological replicates per condition (total $n=12-16$ per condition) for all conditions tested. $A U$ arbitrary units

bind dimeric targets, bevacizumab has the potential to form higher order complexes with VEGF, which under some conditions may act as immune complexes [53]. In contrast, each molecule of VEGF Trap forms an inert 1 to 1 complex with VEGF, and cannot form higher order complexes [35].

The $K_{\mathrm{D}}$ for VEGF Trap binding of VEGF-A documented in the SPR Biacore and KinExA assays translated into increased potency relative to ranibizumab and bevacizumab in all of the bioassays employed. Specifically, VEGF Trap was 33-71-fold more potent than ranibizumab at inhibiting VEGF-A induced receptor activation in cell lines expressing either VEGFR1 or VEGR2 (Table 4). Moreover, VEGF Trap was highly effective at reducing VEGF-A-induced calcium signaling in HUVEC, where it was $\sim 130$-fold more potent than ranibizumab (Table 3). In addition to promoting endothelial cell proliferation and vascular permeability, VEGF-A is powerful mediator of endothelial cell migration [25]. Consistent with the high potency of VEGF Trap to neutralize VEGF receptor activation, VEGF Trap was highly effective at blocking HUVEC migration induced by VEGF$\mathrm{A}_{165}$. In agreement with previous reports [38, 54], ranibizumab and bevacizumab were also effective at decreasing HUVEC migration, though they were less potent than VEGF Trap, such that a 10- to 100-fold molar excess of ranibizumab or bevacizumab was required to completely block VEGF-induced HUVEC migration, while VEGF Trap was effective at equimolar concentrations. 
In the present studies, the ability of ranibizumab to neutralize VEGF-A activity in cell-based assays was only moderately better than that of bevacizumab. For example, the $\mathrm{IC}_{50}$ values for inhibition of activation of VEGFR 1 and VEGFR2 by 20 pM VEGF-A were less than twofold lower for ranibizumab than bevacizumab (Table 3). This corresponded closely to the observed differences in the binding kinetics of ranibizumab and the full length bivalent bevacizumab antibody, where the $K_{\mathrm{D}}$ of bevacizumab for VEGF-A was within twofold of that of ranibizumab, as determined by both Biacore and KinExA assays (Tables 1, 2 , 4). Interestingly, bevacizumab was $\sim$ fivefold more potent than ranibizumab at neutralizing VEGF-A induced calcium influx in HUVEC. This finding may reflect the $\sim$ threefold faster association rate of bevacizumab (Table 1), as $k_{\mathrm{a}}$ is a critical determinant of potency in relatively acute cell-based assays.

The above findings stand in contrast to those recently described by Yu et al. [40]. Specifically, ranibizumab and VEGF Trap were reported to be equally effective in blocking endothelial cell proliferation and migration in HUVEC, while bevacizumab was approximately tenfold less potent. Evaluation of MAPK phosphorylation, which reflects activation of intracellular signaling pathways downstream of the VEGF receptors, showed that all three agents completely blocked MAPK phosphorylation when the VEGF inhibitors were pre-incubated with VEGF-A overnight, before addition to the cells, while VEGF Trap was more potent than either ranibizumab or bevacizumab when preincubated with VEGF-A for shorter time periods (5 and $30 \mathrm{~min}$ ). The apparent discrepancies with findings of the present study are likely attributable to the fact that $\mathrm{Yu}$ et al. [40] utilized higher concentrations of exogenous VEGF-A in all of their cell-based assays, in the range of 0.15-1.25 nM. In other words, the concentration of ligand was above the $K_{\mathrm{D}}$ values for ranibizumab and bevacizumab, as well as VEGF Trap (Table 1); under these assay conditions the $\mathrm{IC}_{50}$ is determined primarily by the concentration of ligand relative to that of the blocker, rather than by the binding affinity. Therefore, precise evaluation of the relative activity of different inhibitors in bioassays requires utilization of the lowest amount of VEGF-A practicable, so that the $\mathrm{IC}_{50}$ can reflect differences in binding affinity and not simply inhibition of activity at stoichiometric concentrations of inhibitor, which predominates under conditions where both antibody and ligand concentrations are well above the $K_{\mathrm{D}}$.

For example, several studies published to date have reported that ranibizumab and bevacizumab are equally effective in neutralizing VEGF-induced endothelial cell proliferation at 'clinically relevant' concentrations, i.e., those that obtain in the eye shortly following intravitreal injection [38, 55], which are well above the equilibrium dissociation constants for both antibodies. Differences in activity emerge only when lower concentrations of drug are evaluated, or where acute bioassay readouts reflect differences in association rate constants. For example, Klettner et al. [39], reported that at lower concentrations ranibizumab more efficiently neutralized VEGF secreted from retinal-choroidal cultures than did bevacizumab. Costa et al. [54] also reported that ranibizumab was moderately more effective at inhibiting endothelial cell proliferation than bevacizumab, while in an acute assay bevacizumab more effectively inhibited VEGF-stimulated VEGFR2 and MAPK phosphorylation in human microvascular endothelial cells.

Binding kinetics and affinity are key determinants of the biological activity of antibody-like drugs. In addition to binding affinity, the activity of a drug is also influenced by the concentration present at the site of target activity, which is in turn dependent on tissue distribution and clearance, with larger molecules typically having longer half-lives. With respect to ocular delivery, it was estimated that biologically active concentrations of ranibizumab would be maintained in the vitreous for approximately 4 weeks following intravitreal injections of $0.5 \mathrm{mg}$ $[26,56]$. Indeed, monthly injection of $0.5 \mathrm{mg}$ ranibizumab has proven to be the most effective regimen for the treatment of neovascular AMD, based on the outcomes of several phase III clinical trials [29, 57-60], and is the currently approved regimen for treating this disease. Using mathematical modeling, and the then available information on intravitreal clearance and binding affinities, Stewart [61] predicted that the anti-VEGF bioactivity present in the vitreous 30 days following intravitreal (IVT) injection of $0.5 \mathrm{mg}$ ranibizumab would be equivalent to that present at 27-38 days following an injection of $1.25 \mathrm{mg}$ bevacizumab. More recently, using the same modeling approach, Stewart and Rosenfeld [62] predicted the intraocular biological activity comparable to that of $0.5 \mathrm{mg}$ ranibizumab at 30 days post-injection would be maintained for approximately twice that time following injection of $0.5 \mathrm{mg}$ VEGF Trap, and potentially as long as 12 weeks following IVT injection of $2 \mathrm{mg}$ VEGF Trap. This substantial theoretical increase in the relative duration of VEGF neutralizing activity was driven primarily by the higher binding affinity of VEGF Trap for VEGF-A compared to ranibizumab, with a lesser contribution of the predicted longer intravitreal half-life of VEGF Trap (e.g. 4.7 days in rabbits, compared to $\sim 2.9$ days for ranibizumab, [63, 64]. Thus, modeling studies suggested that intravitreal administration of the current clinical doses of ranibizumab and bevacizumab would result in effective VEGF-A inhibition of relatively similar duration, while VEGF Trap might be as efficacious as ranibizumab, but with less frequent dosing. 
While it remains to be unequivocally determined whether the durations of bioactivity of these VEGF blockers predicted by the above modeling studies will be confirmed by clinical experience, data available to date suggest that the results of these modeling studies may prove reasonably accurate. For example, several clinical studies have investigated alternative strategies to monthly ranibizumab injection, including quarterly (every 3 months) or pro renata $(\mathrm{PRN})$ injections following a treatment initiation phase comprising 3 monthly loading doses. Most large, well-controlled studies conducted to date have found that improvements in visual acuity attained during the initiation phase are lost during the quarterly or PRN maintenance phases [58-60, 65]. The recent CATT Trial produced the best results obtained to date using PRN dosing of ranibizumab, which was statistically non-inferior to that of monthly ranibizumab. This may reflect the fact that in the CATT study patients were followed monthly and rigorous criteria were established for retreatment [32]. Nevertheless, the mean improvement in visual acuity attained in CATT using PRN ranibizumab was 1.6 letters below that of monthly ranibizumab, at the end of 1 year. Importantly, the effect of bevacizumab given monthly on visual outcomes was within 0.4 letters of that obtained with ranibizumab given monthly. However, bevacizumab administered PRN failed non-inferiority comparisons to monthly regimens for both antibodies, despite the fact that it was administered more frequently than ranibizumab PRN. These findings are in line with the predictions of modeling studies, as well as the results of the present report, which indicate that the binding affinity and in vitro activity of bevacizumab are moderately less than those of ranibizumab. Several additional large scale controlled trials are currently in progress to evaluate the effects of these two antibodies in patients with neovascular AMD, using both fixed and PRN dosing schedules [31]. These studies, together with outcomes from the CATT trial following longer-term treatment, should provide a clearer picture of the relative clinical activity, and safety, of ranibizumab and bevacizumab.

Although fewer clinical trials have been conducted to date with VEGF Trap-Eye, the available data suggest that, as predicted in modeling studies, the increased affinity of VEGF Trap for VEGF-A may be reflected in clinical activity. For example, in a recent double masked phase 2 trial (CLEAR-IT 2) patients with exudative AMD were randomized to an initiation phase of either a single, or monthly IVT injections of VEGF Trap for 12 weeks at doses of either 0.5 or $2 \mathrm{mg}$. Patients were then switched to a PRN regimen at their originally assigned doses. Reports of the 1 year results described maintenance of statistically significant improvements in vision, retinal thickness and size of the CNV lesions [66, 67]. Here, patients initially dosed on a $2.0 \mathrm{mg}$ monthly schedule received, on average, only 1.6 additional injections during the 40 week PRN period, and those initially dosed on a $0.5 \mathrm{mg}$ monthly schedule received, on average, 2.5 injections. More recently, 1 year results have been reported from two phase 3 clinical trials (VIEW 1 and VIEW 2) in which VEGF Trap-Eye was dosed monthly at 0.5 or $2.0 \mathrm{mg}$ in patients with wet AMD, or at $2.0 \mathrm{mg}$ every other month following an initiation phase of 3 monthly doses. All VEGF Trap-Eye treatment arms, including the $2.0 \mathrm{mg}$ every other month treatment regimen, produced improvements in visual acuity that were equivalent to that obtained in patients dosed with $0.5 \mathrm{mg}$ ranibizumab monthly [68, 69].

The development of ranibizumab has demonstrated that binding multiple VEGF-A isoforms is of substantial benefit in the treatment of neovascular AMD, compared to treatment with pegaptanib, which binds only the 165 isoform of VEGF-A [23, 29, 57, 70-72]. Recent studies have implicated additional VEGF family members, notably PIGF and VEGF-B, in the pathology of ocular vascular diseases as well as some cancers [8, 16, 73]. Therefore, a unique potential advantage of VEGF Trap relative to ranibizumab and bevacizumab is that it also binds VEGF-B and PlGF with high affinity. PlGF in particular has been shown to act in concert with VEGF-A to promote pathological angiogenesis, vascular leak and inflammation [8, 11, 18, 74], and like VEGF-A, levels of PIGF are elevated in the eyes of patients with diverse ocular vascular diseases, including wet AMD [15, 75]. Furthermore, genetic deletion or pharmacological inhibition of PIGF has been shown to inhibit choroidal neovascularization and inflammation, and to enhance the activity of VEGF-A targeted molecules in animal models of choroidal neovascularization [13, 16]. More recently, it has been reported that overexpression of VEGF-B in the murine retina, via adeno-associated virus gene transfer, also promotes retinal and choroidal neovascularization and blood-retinal barrier breakdown [76]. These studies suggest that targeting PlGF and VEGF-B, in addition to VEGF-A, could be of added benefit in treating angiogenic ocular disorders.

Similarly, targeting these additional factors may be important in the oncology setting. First, these VEGF family ligands, most notably PIGF, have been implicated in promoting tumor growth [8, 16, 73], therefore inhibiting these factors, in addition to VEGF-A, may prove therapeutically beneficial in treating cancer. Bevacizumab, which inhibits only VEGF-A, is approved for use in various cancer treatment settings. VEGF Trap, while not currently approved for use, has also exhibited efficacy in the oncology setting. Most recently it was reported to have an overall survival benefit in metastatic colorectal cancer [77]. Changes in the levels of PlGF and other factors have been observed in patients with metastatic colorectal cancer treated with bevacizumab, during and following cessation 
of treatment [78, 79], and the authors of both studies suggested that increases in other pro-angiogenic factors may be one mechanism underlying the development of resistance to anti-VEGF therapy. However, further prospective evaluations are needed to confirm these hypotheses.

In summary, VEGF Trap demonstrated higher binding affinity for VEGF-A isoforms and greater potency in vitro than ranibizumab or bevacizumab. These attributes, in addition to its ability to bind VEGF-B and PIGF, could be of added benefit in treating various ocular disorders and cancers.

Acknowledgments The authors thank Douglas MacDonald for carefully reviewing the data included in this paper and Katherine Woloshin for assistance in preparing the manuscript and figures. We also thank our research associates for their assistance in the conduct of these studies, and our colleagues at Regeneron, Sanofi, and Bayer HealthCare for their critical reading of this manuscript, and many helpful comments and suggestions.

Conflict of interest All of the authors are employed by Regeneron Pharmaceuticals, Inc. and hold equity positions in the company.

Open Access This article is distributed under the terms of the Creative Commons Attribution License which permits any use, distribution, and reproduction in any medium, provided the original author(s) and the source are credited.

\section{References}

1. Grothey A, Galanis E (2009) Targeting angiogenesis: progress with anti-VEGF treatment with large molecules. Nat Rev Clin Oncol 6:507-518

2. Bressler SB (2009) Introduction: understanding the role of angiogenesis and antiangiogenic agents in age-related macular degeneration. Ophthalmology 116:S1-S7

3. Bressler NM (2004) Age-related macular degeneration is the leading cause of blindness. JAMA 291:1900-1901

4. Folkman J (2007) Angiogenesis: an organizing principle for drug discovery? Nat Rev Drug 6:273-286

5. Baluk P, Hashizume H, McDonald DM (2005) Cellular abnormalities of blood vessels as targets in cancer. Curr Opin Genet Dev 15:102-111

6. Carmeliet P, Jain RK (2000) Angiogenesis in cancer and other diseases. Nature 407:249-257

7. Crawford Y, Ferrara N (2009) VEGF inhibition: insights from preclinical and clinical studies. Cell Tissue Res 335:261-269

8. Cao Y (2009) Positive and negative modulation of angiogenesis by VEGFR1 ligands. Sci Signal 2:rel

9. Dvorak HF, Nagy JA, Feng D, Brown LF, Dvorak AM (1999) Vascular permeability factor/vascular endothelial growth factor and the significance of microvascular hyperpermeability in angiogenesis. Curr Top Microbiol Immunol 237:97-132

10. Miller JW, Adamis AP, Aiello LP (1997) Vascular endothelial growth factor in ocular neovascularization and proliferative diabetic retinopathy. Diabetes Metab Rev 13:37-50

11. Carmeliet P, Moons L, Luttun A, Vincenti V, Compernolle V, De Mol M, Wu Y, Bono F, Devy L, Beck H, Scholz D, Acker T,
DiPalma T, Dewerchin M, Noel A, Stalmans I, Barra A, Blacher S, Vandendriessche T, Ponten A, Eriksson U, Plate KH, Foidart JM, Schaper W, Charnock-Jones DS, Hicklin DJ, Herbert JM, Collen D, Persico MG (2001) Synergism between vascular endothelial growth factor and placental growth factor contributes to angiogenesis and plasma extravasation in pathological conditions. Nat Med 7:575-583

12. Mitamura Y, Tashimo A, Nakamura Y, Tagawa H, Ohtsuka K, Mizue Y, Nishihira J (2002) Vitreous levels of placenta growth factor and vascular endothelial growth factor in patients with proliferative diabetic retinopathy. Diabetes Care 25:2352

13. Rakic JM, Lambert V, Devy L, Luttun A, Carmeliet P, Claes C, Nguyen L, Foidart JM, Noel A, Munaut C (2003) Placental growth factor, a member of the VEGF family, contributes to the development of choroidal neovascularization. Invest Ophthalmol Vis Sci 44:3186-3193

14. Schlingemann RO, Witmer AN (2009) Treatment of retinal diseases with VEGF antagonists. Prog Brain Res 175:253-267

15. Witmer AN, Vrensen GF, Van Noorden CJ, Schlingemann RO (2003) Vascular endothelial growth factors and angiogenesis in eye disease. Prog Retin Eye Res. 22:1-29

16. Van de Veire S, Stalmans I, Heindryckx F, Oura H, TijerasRaballand A, Schmidt T, Loges S, Albrecht I, Jonckx B, Vinckier S, Van Steenkiste C, Tugues S, Rolny C, De Mol M, Dettori D, Hainaud P, Coenegrachts L, Contreres JO, Van Bergen T, Cuervo H, Xiao WH, Le Henaff C, Buysschaert I, Kharabi Masouleh B, Geerts A, Schomber T, Bonnin P, Lambert V, Haustraete J, Zacchigna S, Rakic JM, Jimenez W, Noel A, Giacca M, Colle I, Foidart JM, Tobelem G, MoralesRuiz M, Vilar J, Maxwell P, Vinores SA, Carmeliet G, Dewerchin M, Claesson-Welsh L, Dupuy E, Van Vlierberghe H, Christofori G, Mazzone M, Detmar M, Collen D, Carmeliet P (2010) Further pharmacological and genetic evidence for the efficacy of PlGF inhibition in cancer and eye disease. Cell 141:178-190

17. Ferrara N, Gerber HP, LeCouter J (2003) The biology of VEGF and its receptors. Nat Med 9:669-676

18. Takahashi H, Shibuya M (2005) The vascular endothelial growth factor (VEGF)/VEGF receptor system and its role under physiological and pathological conditions. Clin Sci (Lond) 109:227-241

19. Alitalo K, Carmeliet P (2002) Molecular mechanisms of lymphangiogenesis in health and disease. Cancer Cell 1:219-227

20. Dumont DJ, Jussila L, Taipale J, Lymboussaki A, Mustonen T, Pajusola K, Breitman M, Alitalo K (1998) Cardiovascular failure in mouse embryos deficient in VEGF receptor-3. Science 282:946-949

21. Tammela T, Zarkada G, Wallgard E, Murtomäki A, Suchting S, Wirzenius M, Waltari M, Hellström M, Schomber T, Peltonen R, Freitas C, Duarte A, Isoniemi H, Laakkonen P, Christofori G, Ylä-Herttuala S, Shibuya M, Pytowski B, Eichmann A, Betsholtz C, Alitalo K (2008) Blocking VEGFR-3 suppresses angiogenic sprouting and vascular network formation. Nature 454:656660

22. Tammela T, Zarkada G, Nurmi H, Jakobsson L, Heinolainen K, Tvorogov D, Zheng W, Franco CA, Murtomäki A, Aranda E, Miura N, Ylä-Herttuala S, Fruttiger M, Mäkinen T, Eichmann A, Pollard JW, Gerhardt H, Alitalo K (2011) VEGFR-3 controls tip to stalk conversion at vessel fusion sites by reinforcing Notch signalling. Nat Cell Biol 13:1202-1213

23. Gragoudas ES, Adamis AP, Cunningham ET Jr, Feinsod M, Guyer DR (2004) Pegaptanib for neovascular age-related macular degeneration. N Engl J Med 351:2805-2816

24. Ng EW, Shima DT, Calias P, Cunningham ET Jr, Guyer DR, Adamis AP (2006) Pegaptanib, a targeted anti-VEGF aptamer for ocular vascular disease. Nat Rev Drug Discov 5:123-132 
25. Ferrara N, Hillan KJ, Gerber HP, Novotny W (2004) Discovery and development of bevacizumab, an anti-VEGF antibody for treating cancer. Nat Rev Drug Discov 3:391-400

26. Ferrara N, Damico L, Shams N, Lowman H, Kim R (2006) Development of ranibizumab, an anti-vascular endothelial growth factor antigen binding fragment, as therapy for neovascular agerelated macular degeneration. Retina 26:859-870

27. Campochiaro PA (2007) Targeted pharmacotherapy of retinal diseases with ranibizumab. Drugs Today (Barc) 43:529-537

28. Chen Y, Wiesmann C, Fuh G, Li B, Christinger HW, McKay P, de Vos AM, Lowman HB (1999) Selection and analysis of an optimized anti-VEGF antibody: crystal structure of an affinitymatured Fab in complex with antigen. J Mol Biol 293:865-881

29. Rosenfeld PJ, Brown DM, Heier JS, Boyer DS, Kaiser PK, Chung CY, Kim RY (2006) Ranibizumab for neovascular age-related macular degeneration. N Engl J Med 355:1419-1431

30. Monés J (2010) A review of ranibizumab clinical trial data in exudative age-related macular degeneration and how to translate it into daily practice. Ophthalmologica 225:112-119

31. Ziemssen F, Grisanti S, Bartz-Schmidt KU, Spitzer MS (2009) Off-label use of bevacizumab for the treatment of age-related macular degeneration: what is the evidence? Drugs Aging 26:295-320

32. The CATT Research Group, Martin DF, Maguire MG, Ying GS, Grunwald JE, Fine SL, Jaffe GJ (2011) Ranibizumab and bevacizumab for neovascular age-realted macular degeneration. N Engl J Med 364:1897-1908

33. Economides AN, Carpenter LR, Rudge JR, Wong V, KoehlerStec EM, Hartnett C, Pyles EA, Xu X, Daly TJ, Young MR, Fandl JP, Lee F, Carver S, McNay J, Bailey K, Ramakanth S, Hutabarat R, Huang TT, Radziejewski C, Yancopoulos GD, Stahl N (2003) Cytokine traps: multi-component, high-affinity blockers of cytokine action. Nat Med 9:47-52

34. Holash J, Davis S, Papadopoulos N, Croll SD, Ho L, Russell M, Boland P, Leidich R, Hylton D, Burova E, Ioffe E, Huang T, Radziejewski C, Bailey K, Fandl JP, Daly T, Wiegand SJ, Yancopoulos GD, Rudge JS (2002) VEGF-Trap: a VEGF blocker with potent antitumor effects. Proc Natl Acad Sci USA 99:11393-11398

35. Rudge JS, Holash J, Hylton D, Russell M, Jiang S, Leidich R, Papadopoulos N, Pyles EA, Torri A, Wiegand SJ, Thurston G, Stahl N, Yancopoulos GD (2007) VEGF Trap complex formation measures production rates of VEGF, providing a biomarker for predicting efficacious angiogenic blockade. Proc Natl Acad Sci USA 104:18363-18370

36. Presta LG, Chen H, O'Connor SJ, Chisholm V, Meng YG, Krummen L, Winkler M, Ferrara N (1997) Humanization of an anti-vascular endothelial growth factor monoclonal antibody for the therapy of solid tumors and other disorders. Cancer Res 57:4593-4599

37. Lowe J, Araujo J, Yang J, Reich M, Oldendorp A, Shiu V, Quarmby V, Lowman H, Lien S, Gaudreault J, Maia M (2007) Ranibizumab inhibits multiple forms of biologically active vascular endothelial growth factor in vitro and in vivo. Exp Eye Res $85: 425-430$

38. Carneiro A, Falcao M, Pirraco A, Milheiro-Oliveira P, FalcaoReis F, Soares R (2009) Comparative effects of bevacizumab, ranibizumab and pegaptanib at intravitreal dose range on endothelial cells. Exp Eye Res 88:522-527

39. Klettner A, Roider J (2008) Comparison of bevacizumab, ranibizumab, and pegaptanib in vitro: efficiency and possible additional pathways. Invest Ophthalmol Vis Sci 49:4523-4527

40. Yu L, Liang XH, Ferrara N (2011) Comparing protein VEGF inhibitors: in vitro biological studies. Biochem Biophys Res Commun 408:276-281
41. Drake AW, Myszka DG, Klakamp SL (2004) Characterizing high-affinity antigen/antibody complexes by kinetic- and equilibrium-based methods. Anal Biochem 328:35-43

42. Myszka DG (1999) Improving biosensor analysis. J Mol Recognit 12:279-284

43. Darling RJ, Brault PA (2004) Kinetic exclusion assay technology: characterization of molecular interactions. Assay Drug Dev Technol 2:647-657

44. Quinn TP, Peters KG, De Vries C, Ferrara N, Williams LT (1993) Fetal liver kinase 1 is a receptor for vascular endothelial growth factor and is selectively expressed in vascular endothelium. Proc Natl Acad Sci USA 90:7533-7537

45. Waltenberger J, Claesson-Welsh L, Siegbahn A, Shibuya M, Heldin CH (1994) Different signal transduction properties of KDR and Flt1, two receptors for vascular endothelial growth factor. J Biol Chem 269:26988-26995

46. Fuh G, Wu P, Liang WC, Ultsch M, Lee CV, Moffat B, Wiesmann C (2006) Structure-function studies of two synthetic antivascular endothelial growth factor Fabs and comparison with the Avastin Fab. J Biol Chem 10;281:6625-6631

47. Yu L, Wu X, Cheng Z, Lee CV, LeCouter J, Campa C, Fuh G, Lowman H, Ferrara N (2008) Interaction between bevacizumab and murine VEGF-A: a reassessment. Invest Ophthalmol Vis Sci 49:522-527

48. Lu F, Adelman RA (2009) Are intravitreal bevacizumab and ranibizumab effective in a rat model of choroidal neovascularization? Graefes Arch Clin Exp Ophthalmol 247:171-177

49. Meyer RD, Singh A, Majnoun F, Latz C, Lashkari K, Rahimi N (2004) Substitution of C-terminus of VEGFR-2 with VEGFR-1 promotes VEGFR-1 activation and endothelial cell proliferation. Oncogene 23:5523-5531

50. Dawson NS, Zawieja DC, Wu MH, Granger HJ (2006) Signaling pathways mediating VEGF165-induced calcium transients and membrane depolarization in human endothelial cells. FASEB J 20:991-993

51. Yoshida A, Anand-Apte B, Zetter BR (1996) Differential endothelial migration and proliferation to basic fibroblast growth factor and vascular endothelial growth factor. Growth Factors 13:57-64

52. Hauser S, Weich HA (1993) A heparin-binding form of placenta growth factor (PlGF-2) is expressed in human umbilical vein endothelial cells and in placenta. Growth Factors 9:259-268

53. Meyer T, Robles-Carrillo L, Robson T, Langer F, Desai H, Davila M, Amaya M, Francis JL, Amirkhosravi A (2009) Bevacizumab immune complexes activate platelets and induce thrombosis in FCGR2A transgenic mice. J Thromb Haemost $7: 171-181$

54. Costa R, Carneiro A, Rocha A, Pirraco A, Falcao M, Vasques L, Soares R (2009) Bevacizumab and ranibizumab on microvascular endothelial cells: a comparative study. J Cell Biochem 108:1410-1417

55. Spitzer MS, Yoeruek E, Sierra A, Wallenfels-Thilo B, Schraermeyer U, Spitzer B, Bartz-Schmidt KU, Szurman P (2007) Comparative antiproliferative and cytotoxic profile of bevacizumab (Avastin), pegaptanib (Macugen) and ranibizumab (Lucentis) on different ocular cells. Graefes Arc Clin Exp Ophthalmol 245:1837-1842

56. Gaudreault J, Fei D, Rusit J, Suboc P, Shiu V (2005) Preclinical pharmacokinetics of Ranibizumab (rhuFabV2) after a single intravitreal administration. Invest Ophthalmol Vis Sci 46:726-733

57. Brown DM, Kaiser PK, Michels M, Soubrane G, Heier JS, Kim RY, Sy JP, Schneider S (2006) Ranibizumab versus verteporfin for neovascular age-related macular degeneration. N Engl J Med 355:1432-1444

58. Regillo CD, Brown DM, Abraham P, Yue H, Ianchulev T, Schneider S, Shams N (2008) Randomized, double-masked, 
sham-controlled trial of ranibizumab for neovascular age-related macular degeneration: PIER Study year 1. Am J Ophthalmol 145:239-248

59. Schmidt-Erfurth U, Eldem B, Guymer R, Korobelnik JF, Schlingemann RO, Axer-Siegel R, Wiedemann P, Simader C, Gekkieva M, Weichselberger A (2011) Efficacy and safety of monthly versus quarterly ranibizumab treatment in neovascular age-related macular degeneration the EXCITE study. Ophthalmology 118:831-839

60. Holz FG, Amoaku W, Donate J, Guymer RH, Kellner U, Schlingemann RO, Weichselberger A, Staurenghi G (2011) Safety and efficacy of a flexible dosing regimen of ranibizumab in neovascular age-related macular degeneration: the SUSTAIN study. Ophthalmology 118:663-671

61. Stewart MW (2007) Predicted biologic activity of intravitreal bevacizumab. Retina 27:1196-1200

62. Stewart MW, Rosenfeld PJ (2008) Predicted biological activity of intravitreal VEGF Trap. Br J Ophthalmol 92:667-668

63. Furfine E, Coppi A, Koehler-Stec E, Zimmer E, Tu W, Struble C. Pharmacokinetics and ocular tissue penetration of VEGF Trap after intravitreal injections in rabbits. Invest Opthalmol Vis Sci 47:E-abstract 1430

64. Bakri SJ, Snyder MR, Reid JM, Pulido JS, Ezzat MK, Singh RJ (2007) Pharmacokinetics of intravitreal ranibizumab (Lucentis). Ophthalmology 114:2179-2182

65. Boyer DS, Heier JS, Brown DM, Francom SF, Ianchulev T, Rubio RG (2009) A Phase IIIb study to evaluate the safety of ranibizumab in subjects with neovascular age-related macular degeneration. Ophthalmology 116:1731-1739

66. Brown DM, Heier JS, Ciulla T, Benz M, Abraham P, Yancopoulos G, Stahl N, Ingerman A, Vitti R, Berliner AJ, Yang K, Nguyen QD, CLEAR-IT 2 Investigators (2011) Primary endpoint results of a phase II study of vascular endothelial growth factor trap-eye in wet age-related macular degeneration. Ophthalmology 118:1089-1097

67. Heier JS, Boyer D, Nguyen QD, Marcus D, Roth DB, Yancopoulos G, Stahl N, Ingerman A, Vitti R, Berliner AJ, Yang K, Brown DM, CLEAR-IT 2 Investigators (2011) The 1-year results of CLEAR-IT 2, a phase 2 study of vascular endothelial growth factor trap-eye dosed as-needed after 12-week fixed dosing. Ophthalmology 118:1098-1106

68. Nguyen QD, Heier J, Brown D, Ho A, Kaiser P, Vitti R, VIEW 1 Study Group (2011) Randomized, double-masked, active-controlled phase 3 trial of the efficacy and safety of intravitreal VEGF Trap-eye in Wet AMD: one-year results of the view-1 study. Invest Ophthalmol Vis Sci 52:E-abstract 3073

69. Schmidt-Erfurth U, Chong V, Kirchhof B, Korobelnik JF, Papp A, Anderesi M, Groetzbach G, Sommerauer B, Sandbrink R, Ogura Y (2011) Primary results of an international phase III study using intravitreal VEGF trap-eye compared to ranibizumab in patients with Wet AMD (VIEW2). Invest Ophthalmol Vis Sci 52:E-abstract 1650
70. VEGF Inhibition Study in Ocular Neovascularization (V.I.S.I.O.N.) Clinical Trial Group, Chakravarthy U, Adamis AP, Cunningham ET Jr, Goldbaum M, Guyer DR, Katz B, Patel M (2006) Year-2 efficacy results of 2 randomized controlled clinical trials of pegaptanib for neovascular age-related macular degeneration. Ophthalmology 113:1508.e1-1508.e25

71. Ciulla TA, Rosenfeld PJ (2009) Antivascular endothelial growth factor therapy for neovascular age-related macular degeneration. Curr Opin Ophthalmol 20:158-165

72. Moussa S, Ansari-Shahrezaei S, Smretschnig E, Hagen S, Steindl-Kuscher K, Krebs I, Binder S (2010) Contrast sensitivity after intravitreal antivascular endothelial growth factor therapy for myopic choroidal neovascularization. Graefes Arch Clin Exp Ophthalmol 248:1087-1090

73. Yao J, Wu X, Kasman IM, Vogt T, Phan V, Shibuya M, Ferrara N, Bais C (2011) Expression of a functional VEGFR-1 in tumor cells is a major determinant of anti-PlGF antibodies efficacy. Proc Natl Acad Sci USA 108:11590-11595

74. Luttun A, Tjwa M, Moons L, Wu Y, Angelillo-Scherrer A, Liao F, Nagy JA, Hooper A, Priller J, De Klerck B, Compernolle V, Daci E, Bohlen P, Dewerchin M, Herbert JM, Fava R, Matthys P, Carmeliet G, Collen D, Dvorak HF, Hicklin DJ, Carmeliet P (2002) Revascularization of ischemic tissues by PlGF treatment, and inhibition of tumor angiogenesis, arthritis and atherosclerosis by anti-Flt1. Nat Med 8:831-840

75. Miyamoto N, de Kozak Y, Jeanny JC, Glotin A, Mascarelli F, Massin P, BenEzra D, Behar-Cohen F (2007) Placental growth factor-1 and epithelial haemato-retinal barrier breakdown: potential implication in the pathogenesis of diabetic retinopathy. Diabetologia 50:461-470

76. Zhong X, Huang H, Shen J, Zacchigna S, Zentilin L, Giacca M, Vinores SA (2011) Vascular endothelial growth factor-B gene transfer exacerbates retinal and choroidal neovascularization and vasopermeability without promoting inflammation. Mol Vis 17:492-507

77. Van Cutsem E, Tabernero J, Lakomy R et al. Intravenous (IV) aflibercept versus placebo in combination with irinotecan/5-FU (FOLFIRI) for second-line treatment of metastatic colorectal cancer (MCRC): Results of a multinational phase III trial (EFC10262-VELOUR). Ann Oncol 22(supplement 5): v10-v18. Abstract O-0024

78. Kopetz S, Hoff PM, Morris JS, Wolff RA, Eng C, Glover KY, Adinin R, Overman MJ, Valero V, Wen S, Lieu C, Yan S, Tran HT, Ellis LM, Abbruzzese JL, Heymach JV (2010) Phase II trial of infusional fluorouracil, irinotecan, and bevacizumab for metastatic colorectal cancer: efficacy and circulating angiogenic biomarkers associated with therapeutic resistance. J Clin Oncol 28:453-459

79. Lieu C, Tran H, Jian Z, Mao M, Overman M, Eng C, Morris J, Ellis L, Heymach J, Kopetz S. The association of alternate VEGF ligands with resistance to anti-VEGF therapy in metastatic colorectal cancer (mCRC). J Clin Oncol 29:suppl. abstr 3533 